\title{
Enhancement of Biogas Production from Mixed Organic Substrates Containing Cow Manure and Delignified Spent Coffee Grounds (SCG) by Addition of Effective Microorganism - 4
}

Indro - Sumantri ( $\square$ indrotekim@yahoo.com )

Universitas Diponegoro https://orcid.org/0000-0002-1242-4877

Peter - Kusnadi

Universitas Diponegoro

I. Gelbert Reinaldo Handoyo

Universitas Diponegoro

Andri Cahyo Kumoro

Universitas Diponegoro

Research

Keywords: EM-4, spent coffee ground (SCG), biogas, anaerobic digestion, Gompertz equation

Posted Date: February 3rd, 2021

DOl: https://doi.org/10.21203/rs.3.rs-159437/v1

License: (c) (1) This work is licensed under a Creative Commons Attribution 4.0 International License.

Read Full License 


\section{Abstract}

There have been continuous efforts to find environmentally benign energy to cope steady increase of global energy needs. The spent coffee ground (SCG) is one of agricultural wastes that can be utilized as a raw material to produce biogas. This study aims to produce biogas from mixture of organic substrate containing cow manure and spent coffee ground (SCG) with a C/N ratio of 25:1 with the addition of effective microorganisms-4 (EM-4) to enhance biogas production. The biodegradations were performed in an anaerobic batch digestion (AD) at ambient environment. The variables used of this research were $\mathrm{pH}(5,7$, and 9$)$ and the loading of EM-4 $(6,9$, and 12\%). The digestions were run for 60 days and the volumes of biogas produced were measured every two days. The results showed that the addition of EM4 was able to initiate biogas production earlier, enhance biogas volume, and extend biogas production end time. The best digestion condition for substrate containing cow manure and SCG with a $\mathrm{C} / \mathrm{N}$ ratio of 25:1 was found to be at pH 9 and EM-4 loading of $9 \%$ to obtain $11.28 \mathrm{~mL}$ biogas/g COD with enhancement of biogas production of about $100.2 \%$. The experimental data was fitted really well by the modified Gompertz equation as shown by a high determination coefficient $\left(R^{2}>0.95\right)$.

\section{Introduction}

The formation of biogas in the anaerobic process occurs through the accomplishment of four steps organic substrates degradation, namely the hydrolysis, acidogenesis, acetogenesis, and methanogenesis. Many previous studies revealed that the anaerobic digestion (AD) is suitable for the treatment of wastewater with high content of organic substances. As compared to aerobic digestion, the AD process offers some superiorities, such as the larger production of biomethane, inorganic nutrients and humus as fertilizer, from which additional benefits from economic and environmental aspects can be achieved. The $A D$ process is a popular method for treating of industrial and agricultural waste [1] and converting the organic substances to produce biomethane. Indeed, $A D$ is also well suited with the tropical climate [2]. In addition to Carbon-Nitrogen ratio, other important factors also play important roles in AD process, such as $\mathrm{pH}$, temperature, solid particle size, volatile fatty acid, organic loading rate, solid retention time, and nutrient concentration [3].

The growth of the microbes is highly affected by the presence of nitrogen as the major nutrient. However, it is also usually depending on the carbon substance as reflected by carbon-nitrogen ratio. For an anaerobic digestion, the carbon-nitrogen ratio usually ranges from 25 to 30 . Although the statement suggests that nitrogen is the limiting nutrient to the AD process. A low supply of nitrogen will cause limited amount of microbial population, while an excess of nitrogen supply can induce the formation of ammonia and cause a longer duration required for carbon degradation. Therefore, the carbon-nitrogen ratio can be used as an indicator of the performance of $A D$ process. The available carbon is an energy source for the microorganisms, while the nitrogen plays its role to control the population of the microorganisms $[4,5]$. 
Cow manure is one of the important livestock wastes generally used in biogas production through anaerobic digestion. The production of biogas as environmentally benign alternative energy from animal manure, especially cows, possesses excellent potential because the residue of the biogas production in the form of slurry can still be utilized as a high-quality organic fertilizer [6]. Cow manure comprises hemicellulose, cellulose and lignin by $18.6 \%, 25.2 \%$ and $20.2 \%$, respectively. Cow manure bears a nitrogen content of $0.3 \%$, phosphate $0.2 \%$, potassium oxide $0.15 \%$ and calcium oxide by $0.2 \%$, which provides an approximate $\mathrm{C} / \mathrm{N}$ ratio of $20-25 \%$ [7]. Therefore, cow manure requires an appropriate supplementation with other materials that have a good $\mathrm{C} / \mathrm{N}$ ratio. The best supplements can be organic materials such as, agricultural waste, kitchen waste and other organic waste [8].

Along with Brazil and Vietnam, Indonesia is regarded as one of the world's largest coffee (Coffea $s p$ ) producers. Approximately $78 \%$ of the total world's coffee beans are produced from Indonesia. Of the total production of 644,000 tons, about $59.2 \%$ is exported and the rest $40.8 \%$ is used to fulfill the domestic demand [9]. At present, coffee is served to consumers in various forms. Its enjoyment has now become part of the lifestyle, which can be linked to informal, formal and business communication, characterized by the emerging of cafés in numerous regions in Indonesia and many other countries. In accordance with the increasing coffee productivity and consumption in Indonesia, vast amount of coffee waste generation is inevitable. Coffee amps contain $12.4 \%$ cellulose, $39.1 \%$ hemicellulose, and $23.9 \%$ lignocellulose, nitrogen: $2.1-2.79, \mathrm{C} / \mathrm{N}$ ratio: 16.91 , fat: 2.29 , protein: 17.44 . [10, 11, 12].

Effective Microorganism-4 (EM-4) is a brownish-colored and sweetly sour (fresh) liquid that is a cocktail of several living microorganisms useful for the anaerobic digestive process for biogas production. Herawati \& Wibawa [13] observed that the addition of EM 4 accelerates the degradation of cellulose, hemicellulose, and lignin into compounds required by biogas-producing microorganisms. Generally, those microorganisms consist of photosynthetic bacteria, lactic acid bacteria, yeast, actinomycetes, and yeast. Inoculant microorganism should consist of $90 \%$ Lactobacillus Sp, which produce lactic acid which can speed up the digestion of lignin and cellulose [14]. The EM-4's inoculate capabilities that can accelerate cellulose, hemicellulose, and lignin degradation can be an excellent choice for use as a mixture of biogasmaking raw materials.

This research aimed to observe the utilization of cow manure and SCG mixture as a substrate and the addition of effective microorganisms-4 to enhance the biomethane production. Although animal manure has been reported as the most popular substrate for full-scale biogas production, it resulted in low biogas yields, therefore an effort to enhance biogas production through co-substrate is proposed [15]. The study was conducted in a batch process at ambient temperature and pressure for 60 days observation with biogas yield was recorded at every 2 days interval. The initial COD of the system and carbon-nitrogen ratio were $37,000 \mathrm{mg} / \mathrm{L}$ and 25 . The research variables were $\mathrm{pH}$ solution $(5,7$, and 9$)$ and addition of EM$4(6,9,12 \%)$. The dependent variables of the research were biogas production and reduction of COD.

\section{Materials}




\section{Cow manure.}

The cow manure used for the biodigestion experiment was not the fresh manure, but that after naturally fermented into compost and locally known as "compost fertilizer". The manure was purchased from an agricultural shop in Semarang, Central Java, Indonesia. Prior to biodigestion experiment, the compost fertilizer was analyzed for its total carbon and nitrogen content. The result of the analysis indicated that the content of the total carbon and nitrogen content were $9.3 \%$ and $0.34 \%$, confirming a carbon-nitrogen ratio of 27.34 [16].

\section{Spent Coffee Grounds}

The spent coffee grounds (SCG) were also collected from some café shops in Semarang, Central Java, Indonesia. The SCG waste was dried in an electric oven at $70^{\circ} \mathrm{C}$ to dryness before further subjected to alkali delignification using $1.5 \mathrm{~N}$ sodium hydroxide solution at $120^{\circ} \mathrm{C}$ for 60 minutes. The delignified SCG was decanted from the solution and washed several times using hot water to remove the residual alkali and further dried in the oven at $120^{\circ} \mathrm{C}$. The delignified SCG contained $49.9 \%$ and $2.70 \%$ total carbon and nitrogen giving carbon-nitrogen ratio of 17.87 [16].

\section{Biodigestion Experiment}

The experiments were run in a batch biodigester (Fig. 1) with the carbon-nitrogen ratio of 25 . Based on the carbon and nitrogen content, a carefully weighed substrate mixture (500 g) could be obtained by mixing of $480.63 \mathrm{~g}$ cow manure and $19.37 \mathrm{~g}$ coffee ground waste.

The substrate feed and EM-4 bacteria mixtures were prepared according to Table 1, and predetermined amount of water with total volume of mixture of $1000 \mathrm{ml}$. Furthermore, the initial $\mathrm{pH}$ of the mixture was set according to Table 1 by addition of a buffer solution. The readily used substrate feed was introduced into the digester and followed by hermetically closed the digester to create an anaerobic condition. As the biodigestion went by, the volume of the produced biogas was recorded. The volume of biogas was quantified using the water displacement method. In addition, the COD measurements using COD reactors and absorbance spectrophotometry were performed at the first day and the 60th day. 
Table 1

Variation of the EM-4 and mixture of cow manure and SCG

\begin{tabular}{|c|c|c|c|c|c|c|}
\hline \multirow[t]{2}{*}{ No } & & \multirow{2}{*}{$\begin{array}{l}\text { Addition of EM-4 } \\
(\%)\end{array}$} & \multicolumn{2}{|c|}{ Cow manure and SCG } & \multirow{2}{*}{$\begin{array}{l}\text { Volume EM-4 } \\
(\mathrm{mL})\end{array}$} & \multirow{2}{*}{$\begin{array}{l}\text { Volume of water } \\
(\mathrm{mL})\end{array}$} \\
\hline & & & $\begin{array}{l}\text { Volume } \\
(\mathrm{mL})\end{array}$ & $\begin{array}{l}\text { COD } \\
(\mathrm{mg} / \mathrm{L})\end{array}$ & & \\
\hline 1 & Control & - & 748 & 37,000 & - & 252.0 \\
\hline \multirow[t]{3}{*}{2} & \multirow[t]{3}{*}{$\mathrm{pH}=5$} & 6 & 748 & 37,000 & 44.9 & 207.4 \\
\hline & & 9 & 748 & 37,000 & 67.3 & 184.7 \\
\hline & & 12 & 748 & 37,000 & 89.8 & 162.2 \\
\hline \multirow[t]{3}{*}{3} & \multirow[t]{3}{*}{$\mathrm{pH}=7$} & 6 & 748 & 37,000 & 44.9 & 207.4 \\
\hline & & 9 & 748 & 37,000 & 67.3 & 184.7 \\
\hline & & 12 & 748 & 37,000 & 89.8 & 162.2 \\
\hline \multirow[t]{3}{*}{4} & \multirow[t]{3}{*}{$\mathrm{pH}=9$} & 6 & 748 & 37,000 & 44.9 & 207.4 \\
\hline & & 9 & 748 & 37,000 & 67.3 & 184.7 \\
\hline & & 12 & 748 & 37,000 & 89.8 & 162.2 \\
\hline
\end{tabular}

\section{Kinetic Model}

Kinetics of the biogas production data obtained from 60 days digestion was evaluated using the modified Gompertz and first-order reaction kinetic models [17]. Both models were developed based on the completion of the anaerobic digestion process, which corresponds to the rate of specific growth of methanogenic bacteria in the digester. The modified Gompertz equation can be written as: 


$$
y(t)=A \cdot \exp \left\{-\exp \left[\frac{\mu e}{A}(\lambda-t)+1\right]\right\}
$$

where:

$$
\begin{aligned}
& \mathrm{y}(\mathrm{t}) \quad=\text { cumulative of specific biogas production }(\mathrm{mL} / \mathrm{g} \mathrm{COD}) \text {. } \\
& A=\text { biogas production potential }(\mathrm{mL} / \mathrm{g} \mathrm{COD}) \\
& \mu \quad=\text { maximum biogas production rate }(\mathrm{mL} / \mathrm{g} \text { COD.day }) \text {, } \\
& \lambda=\text { lag phase period or minimum time to produce biogas (days), } \\
& \text { t = cumulative time for biogas production (days) and } \\
& \text { e } \quad=\text { a constant }(2.718282) \text {. }
\end{aligned}
$$

\begin{tabular}{|c|c|c|c|c|c|c|c|c|}
\hline \multirow[t]{2}{*}{ No } & \multirow[t]{2}{*}{ Variable } & \multirow{2}{*}{$\begin{array}{l}\text { Addition } \\
\text { of EM-4 } \\
(\%)\end{array}$} & \multirow{2}{*}{$\begin{array}{l}\text { Cumulative } \\
\text { biogas } \\
\text { volume }(\mathrm{mL})\end{array}$} & \multirow{2}{*}{$\begin{array}{l}\text { Enhancement } \\
\text { of biogas (\%) }\end{array}$} & \multirow{2}{*}{$\begin{array}{l}\text { COD } \\
\text { influent } \\
\text { (mg/L) }\end{array}$} & \multirow{2}{*}{$\begin{array}{l}\text { COD } \\
\text { effluent } \\
\text { (mg/L) }\end{array}$} & \multicolumn{2}{|c|}{ COD removal } \\
\hline & & & & & & & kg & $\%$ \\
\hline 1 & Control & - & 53.4 & - & 37000 & 24666 & 12334 & 33.34 \\
\hline \multirow[t]{3}{*}{2} & \multirow[t]{3}{*}{$\mathrm{pH}=5$} & 6 & 57.6 & 7.9 & 37000 & 23666 & 13334 & 36.04 \\
\hline & & 9 & 69.5 & 30.1 & 37000 & 22400 & 14600 & 39.46 \\
\hline & & 12 & 67.5 & 26.4 & 37000 & 21333 & 15667 & 42.34 \\
\hline \multirow[t]{3}{*}{3} & \multirow[t]{3}{*}{$\mathrm{pH}=7$} & 6 & 83.4 & 56.2 & 37000 & 16666 & 20334 & 54.96 \\
\hline & & 9 & 106.9 & 100.2 & 37000 & 15533 & 21467 & 58.02 \\
\hline & & 12 & 98.7 & 84.8 & 37000 & 17333 & 19667 & 53.15 \\
\hline \multirow[t]{3}{*}{4} & \multirow[t]{3}{*}{$\mathrm{pH}=9$} & 6 & 71.5 & 33.9 & 37000 & 18200 & 18800 & 50.81 \\
\hline & & 9 & 86.8 & 62.5 & 37000 & 19400 & 17600 & 47.57 \\
\hline & & 12 & 84.2 & 57.7 & 37000 & 20200 & 16800 & 45.41 \\
\hline
\end{tabular}

The kinetics constants of $A, \mu$, and $\lambda$ can be determined through a non-linear regression.

\section{Results And Discussion}

Rate of biogas formation

Table 2

Effect of $\mathrm{pH}$ and EM-4 loading on biogas production enhancement and COD removal. 
Table 2 presents the cumulative and enhancement of biogas production at various $\mathrm{pH}$ and EM-4 loading. The control experiment was performed without addition of EM-4 as an anaerobic digestion enhancer. It is clear that the addition of EM-4 to the substrate mixture in the digestion chamber significantly increased the biogas production. The increasing biogas production for $\mathrm{pH}$ of 5 was 7.9 to $26.4 \%$, $\mathrm{pH}$ of 7 was 56.2 to $100.2 \%$, and for $\mathrm{pH}$ of 9 was 33.9 to $62.5 \%$. Three $\mathrm{pH}$ values were applied in the biodigestion experiments, which all resulted in significant enhancement of the biogas production compared to the control experiment. However, biodigestion conducted at $\mathrm{pH}$ of 7 (neutral condition) demonstrated the highest enhancement of biogas production than at pH 5 (acidic) and 9 (basic) conditions. Table 2 also clearly shows that the addition of EM-4 at $9 \%$ resulted in the highest enhancement of biogas production than that at 6 and 12\%. Overall, the EM-4 provided a positive effect to the enhancement of biogas production because EM-4 is basically a cocktail mixture of living microorganisms that may actively improve the completion of anaerobic digestion. Substrate from food waste generally has higher methane potential production, lignocellulosic biomass, animal manure, and sewage sludge $[18,19]$. The living microorganisms of EM-4 are believed to demonstrate strong capability to degrade the substrate for SCG and cow manure. Previous researchers [20] examined the biogas production utilized of soluble fraction of SCG and cow manure in a batch digester and the result indicated that there was $10 \%$ an increase of biogas production compared to only cow manure as a substrate.

As tabulated in Table 2, the $\mathrm{pH}$ of the system also plays important roles in the anaerobic digestion (AD) process. Previous reports also revealed that the performance of the $A D$ is strongly dependent on $\mathrm{pH}$ because $\mathrm{pH}$ of the system determines the activity of the bacteria groups involve for each stage of $A D[19$, 3]. Under weak acidic condition ( $\mathrm{pH} 5.5$ to 6.5 ), the biodigestion took place through hydrolysis and acidogenesis. Some intermediate products of $A D$, such as volatile fatty acids and acetate are produced during acidogenesis stage, which caused the $\mathrm{pH}$ to decline in the biodigester and subsequently interfere the formation of biogas. In fact, methanogenesis process during $A D$ is the most sensitive to the $\mathrm{pH}$, which is usually optimum at neutral condition $(\mathrm{pH}=7.0 \pm 0.2)[19,3]$. Unfortunately, under basic condition $(\mathrm{pH}=$ 9) the AD because suffer from a decline performance due to reduction of the population of methanogenesis group of bacteria leading to the reduction of biogas formation. As expected, such increment of COD removal rate was achieved from anaerobic biodigestion of mixed organic substrate containing cow manure and SCG via the addition of EM-4 [21]. The trend and performance of COD removal were closely similar with the enhancement of biogas production. The anaerobic biodigestion with the EM-4 addition of $9 \%$ at neutral condition $(\mathrm{pH}=7)$ resulted in the highest enhancement of biogas production and COD removal. 
Table 3

Effect of $\mathrm{pH}$ and EM-4 loading on the biogas production

\begin{tabular}{|c|c|c|c|c|c|c|c|}
\hline \multirow[t]{2}{*}{ No } & \multirow[t]{2}{*}{ Variable } & \multirow[t]{2}{*}{$\begin{array}{l}\text { Addition of } \\
\text { EM-4 (\%) }\end{array}$} & \multirow{2}{*}{$\begin{array}{l}\text { Estimation first of } \\
\text { biogas production } \\
\text { (th day) }\end{array}$} & \multicolumn{2}{|c|}{$\begin{array}{l}\text { Highest biogas } \\
\text { production }\end{array}$} & \multicolumn{2}{|c|}{$\begin{array}{l}\text { Decrease of biogas } \\
\text { production }\end{array}$} \\
\hline & & & & $\begin{array}{l}\text { (th } \\
\text { day) }\end{array}$ & $\begin{array}{l}\text { Vol } \\
(\mathrm{mL} / \mathrm{g} \\
\text { COD) }\end{array}$ & $\begin{array}{l}\text { (th } \\
\text { day) }\end{array}$ & $\begin{array}{l}\text { Vol } \\
(\mathrm{mL} / \mathrm{g} \\
\text { COD) }\end{array}$ \\
\hline 1 & Control & - & 6th & 34th & 3.72 & 36th & 1.96 \\
\hline \multirow[t]{3}{*}{2} & \multirow[t]{3}{*}{$\mathrm{pH}=5$} & 6 & 2nd & $32 n d$ & 5.27 & 46th & 0.41 \\
\hline & & 9 & 2nd & 30th & 7.23 & 46th & 0.61 \\
\hline & & 12 & 2nd & 26th & 7.43 & 38th & 1.96 \\
\hline \multirow[t]{3}{*}{3} & \multirow[t]{3}{*}{$\mathrm{pH}=7$} & 6 & 2nd & 30th & 9.46 & 44th & 1.28 \\
\hline & & 9 & 2nd & 28th & 11.28 & 40th & 1.08 \\
\hline & & 12 & 2nd & 22nd & 11.69 & 38th & 0.68 \\
\hline \multirow[t]{3}{*}{4} & \multirow[t]{3}{*}{$\mathrm{pH}=9$} & 6 & 4th & 30th & 7.77 & 42nd & 2.03 \\
\hline & & 9 & 2nd & 28th & 9.72 & 40th & 0.68 \\
\hline & & 12 & 4th & 24th & 9.32 & 38th & 1.08 \\
\hline
\end{tabular}

Table 3 and Fig. $2(a, b, c)$ present the profile of biogas production as a function of pH of the digestion medium and EM-4 loading. Indeed, all of the studied conditions underwent the same typical biodigestion process, which includes adaptation phase, log phase, stationary phase, and death phase. The biodigestion of mixed substrate under control condition (without addition of EM-4) began to produce biogas at 6 th day digestion and reached the highest biogas production at 34th day (3.72 mL/g COD). The biogas production levelled off at 36th day $(1.96 \mathrm{~mL} / \mathrm{g}$ COD). In the contrary, addition of EM-4 resulted in an earlier biogas production from the first day with higher total volume of biogas than that of control condition.

For biodigestion at weak acidic and neutral conditions ( $\mathrm{pH} 5$ and 7) with addition of 6 to $12 \% \mathrm{EM}-4$, the first biogas production occurred at the 2 nd day of digestion. On the other hand, biodigestion at basic condition ( $\mathrm{pH}=9)$, the biogas production began at 2-4th days and being faster than control condition. The SCG as the co-substrate of the digestion, which mainly consists of cellulose, hemicellulose and lignocellulose was proven to assist the improvement of digestion performance. Previous investigators explained that the SCG has function to improve the $\mathrm{pH}$ value in the biodigester, so that the decline of $\mathrm{pH}$ was less than without SCG $[20,15]$. The cellulose, hemicellulose and lignin contained in the SCG can be easily utilized by EM-4 to accelerate the biogas production. 
The control experiment achieved highest biogas production $(3.72 \mathrm{~mL} / \mathrm{g} \mathrm{COD})$ at the 34th days of digestion. As expected, the digestion system with EM-4 loadings of 6 to $12 \%$ with pH of 5 to 9 required a shorter time to obtain highest biogas production. In addition, EM-4 loading also demonstrated longer time to end the biogas production and resulted in larger cumulative biogas volume. Such increase of EM-4 loadings from 6 to $12 \%$ were able to accelerate the initiation of biogas production compared with the control experiment. As shown in Fig. 2.b, the digestion at neutral condition $(\mathrm{pH}=7)$ demonstrated the best digestion performance for the time to produce highest biogas and accumulative biogas volume than those of digestion under acidic $(\mathrm{pH}=5)$ and basic $(\mathrm{pH}=9)$ conditions. It is clear that he time to end the biogas production is affected by EM-4 loading, by which a higher EM-4 loading will consume more substrate in the biodigester and resulted in a shorter time to end of the digestion. Unfortunately, the rate of biogas production obtained in this study was lower compared with the biodigestion using domestic and restaurant food waste as substrates, which are classified as high-methane yield substrates for their high lipids and other important nutrient contents [22, 23].

During $\mathrm{AD}$ process, the $\mathrm{pH}$ of the biodigestion system plays essential roles because $\mathrm{pH}$ affects the solubilization process [24], sets up desirable environment for microbes [25] and influences the simultaneously occurring enzymatic reactions [26]. The first process of digestion is in acidic $\mathrm{pH}$ and usually maintained at $\mathrm{pH}$ of 5.5-6.5, through a short period (hydraulic retention time of about 2-3 days) acid fermentation [27]. This indicated that at $\mathrm{pH}$ of 5 , the dominant products were acid compounds and a longer time is still required for further biodigestion steps to produce biogas. At higher pH values (neutral and basic conditions), higher biogas production and shorter biodigestion time were observed. However, the digestion at neutral condition $(\mathrm{pH}=7)$ exhibited the best digestion performance for the time to produce highest biogas and accumulative biogas volume than those of other digestion conditions.

\section{Cumulative biogas production}

As seen in Fig. 3, all of the EM-4 loadings provided the similar trends for the cumulative of biogas production at any given time. At pH 5, loading of EM-4 at $6 \%$ only resulted in slightly higher cumulative of biogas volume than that of the control experiment. Surprisingly, loading of EM-4 at 9 and $12 \%$ produced significantly higher cumulative of biogas volume than that of the control experiment, which were 67.5 and $69.5 \mathrm{~mL} / \mathrm{g} \mathrm{COD}$, respectively. It can also be seen that addition of EM-4 was able to shorten the initial biogas production, and hence, reduced the lag time $(\lambda)$ of the Gompertz's kinetic model. Addition of EM- 4 increased the total microorganisms in the biodigestion system and assisted to produce biogas earlier. $\mathrm{A}$ higher value of EM-4 loading resulted in the shorter period of biogas formation due to more microorganisms present in the anaerobic digester. Figure 3.b. presents the wide difference of cumulative biogas production volume between the control experiment and those with EM-4 loadings under neutral condition $(\mathrm{pH}=7)$. Increasing of EM-4 loading resulted in the earlier time to produce biogas (EM-4 loading of $12 \%)$. However, the highest cumulative biogas volume was obtained at biodigestion using EM-4 loading of $9 \%$. 
This phenomenon occurs because the more EM-4 loading means that larger number of microorganisms present in the biodigestion system and effectively degrade the substrate so that the stationer phase is achieved earlier [28]. The death phase of EM-4 loaded at $12 \%$ is achieved earlier than that of $6 \%$ and $9 \%$ loading. Indeed, this situation is likely due to the excellent performance of EM- 4 bacteria that help the process of decaying organic matter, which leads to a faster biogas formation [7]. The speedy substrate degradation process caused a faster the substrate depletion in system, so that the death phase will come very early. Biodigestion experiment with EM-4 loading of $9 \%$ produced the highest total biogas volume compared to that of $6 \%$ and $12 \%$, which could be due to balance between the substrate availability and that is required for the growth of microorganisms.

\section{Kinetic model of biogas production}

The cumulative biogas production data were evaluated using modified Gompertz equation. Results of the kinetic model obtained of modified Gompertz for all experiments are tabulated in Table 4 . The kinetic constant parameters of $A, \mu, \lambda$, and coefficient of determination were obtained from non-linear regression of Gompertz equation. Figure 4 illustrates the comparison of the cumulative biogas production obtained from experiments and simulation using modified Gompertz equation.

The value of $A$ that indicated an ability of the experimental condition to generate the cumulative biogas production. The A value of the control experiment was the lowest compared to the other experimental conditions, which was $54 \mathrm{~mL} / \mathrm{g} \mathrm{COD}$ (Table 4). While, the experiment at neutral condition $(\mathrm{pH}=7)$ with EM-4 loading of $9 \%$ resulted in the highest the cumulative biogas production (108 mL/g COD). Therefore, $\mathrm{pH}=7$ can be concluded as the optimum digestion condition and the addition of EM- 4 of $9 \%$ was proven to enhance the performance of $A D$ to produce biogas.

The value of $\mu$ in the modified Gompertz equation showed the rate of maximum biogas production. The control experiment suffered from the lowest $\mu$ value $(2.28$ ( $\mathrm{mL} / \mathrm{g}$ COD.day) compared to the other experimental conditions, which indicated the slowest biogas production rate. As seen in Table 4 and Fig. 4 , the highest $\mu$ value was achieved by the AD experiment at neutral condition $(\mathrm{pH}=7)$ and $\mathrm{EM}-4$ loading of $12 \%$, which suggested that the faster biogas production from AD by addition of EM-4. Unfortunately, the values of $\mu$ obtained in our experiments were 2.5 to $4.2 \mathrm{~mL} / \mathrm{g}$ COD.day and being lower compared with those obtained by other previous studies (Table 4) which used cattle manure, municipal solid waste, water hyacinth, and poultry litter as substrates $[29,30,31,32]$.

The other important constant of Gompertz equation is $\lambda$, which indicates the minimum time to produce biogas. The control experiment and $\mathrm{AD}$ experiment at $\mathrm{pH}=5$ with EM-4 loading of $6 \%$ both possessed 14 days of $\lambda$. The larger $\lambda$ value is an indication of the longer the time to produce biogas. Hence, the $\lambda$ value can be used to indicate the organic soluble materials of the substrate in the liquid phase which consumed faster by microorganisms in the anaerobic process [33]. In practice, the AD is expected to produce biogas as early as possible. The addition of EM- 4 has been proven to reduce the $\lambda$ value (Table 4), and being advantageous for biogas formation. The AD experiment at neutral condition $(\mathrm{pH}=7)$ with EM-4 loading of $12 \%$ exhibited the lowest $\lambda$ value ( 6 days). As expected, the increase in EM-4 loading 
is beneficial to the AD because more microorganisms available in the system to assist the degradation of organic material to form biogas. However, the lag time $(\lambda)$ values our experiments were higher than those reported by previous studies (Table 4) indicating that degradation of the mixed substrate of cow manure, SCG, and EM-4 was slower. High lignin content in the cow manure could be the cause of the longer degradation time [29].

The comparison between the cumulative biogas production data obtained from experiments and those calculated using the modified Gompertz equation are depicted in Fig. 4. The values of coefficient of determination were high enough ranged from 0.978 to 0.993 (Table 4). These values indicate that modified Gompertz model is a suitable equation to describe the AD of mixed substrate containing cow manure and delignified spent coffee ground (SCG).

Table 4

Kinetic constants of Gompertz equation of biogas production.

\begin{tabular}{|c|c|c|c|c|c|c|}
\hline Variable & Addition of EM-4 & $\begin{array}{l}\mathrm{A}(\mathrm{mL} / \mathrm{g} \\
\mathrm{COD})\end{array}$ & $\begin{array}{l}\mu \text { (mL/g } \\
\text { COD.day) }\end{array}$ & $\stackrel{\lambda}{\text { (days) }}$ & $\mathrm{R}^{2}$ & Author \\
\hline Control & - & 54 & 2.28 & 14 & 0.983 & \multirow{10}{*}{$\begin{array}{l}\text { This } \\
\text { study }\end{array}$} \\
\hline \multirow[t]{3}{*}{$\mathrm{pH}=5$} & $6 \%$ & 58 & 2.75 & 14 & 0.987 & \\
\hline & $9 \%$ & 70 & 2.50 & 9 & 0.978 & \\
\hline & $12 \%$ & 68 & 2.80 & 8 & 0.983 & \\
\hline \multirow[t]{3}{*}{$\mathrm{pH}=7$} & $6 \%$ & 86 & 2.94 & 10 & 0.983 & \\
\hline & $9 \%$ & 108 & 4.07 & 8 & 0.979 & \\
\hline & $12 \%$ & 100 & 4.20 & 6 & 0.986 & \\
\hline \multirow[t]{7}{*}{$\mathrm{pH}=9$} & $6 \%$ & 73 & 2.65 & 10 & 0.981 & \\
\hline & $9 \%$ & 88 & 3.80 & 10 & 0.984 & \\
\hline & $12 \%$ & 85 & 4.01 & 8 & 0.993 & \\
\hline & Cattle manure & 418.260 & 9.490 & 4.460 & - & [29] \\
\hline & $\begin{array}{l}\text { Municipal solid } \\
\text { waste }\end{array}$ & 522 & 97 & 1.2 & 0.983 & [30] \\
\hline & Water Hyacinth & 449.4 & 27.9 & 6.625 & 0.981 & [31] \\
\hline & Poultry litter & 390.4 & 16.5 & 8.749 & 0.999 & [32] \\
\hline
\end{tabular}

\section{Conclusion}


The addition of EM-4 to an anaerobic digestion of mixed substrates containing cow manure and SCG in provided positive effect on the biogas production, COD removal and Gompartz kinetic parameters. Compared with the control experiment without addition of EM-4, the AD experiment with the addition of EM-4 loading increase the biogas production by 44.9 to $89.8 \%$, removal COD of 6.12 to $24.68 \%$, and increased the kinetic parameter of $A, \mu$, and $\lambda$. An $A D$ process at neutral condition and $E M-4$ loading of $9 \%$ with substrate containing $\mathrm{C} / \mathrm{N}$ ratio of 25 resulted the best condition of biogas production, COD removal and biodegradation kinetic parameters. The result of the experiments promised that utilization of SCG with addition of EM-4 can be used to both treatment of solid waste of coffee and generation of biogas as green energy.

\section{Declarations}

\section{Conflict of interest}

The authors declare no competing financial interest.

\section{Acknowledgements}

The authors gratefully thank to the laboratory facilities in Universitas Diponegoro and Wastewater Technology Laboratory of Department of Chemical Engineering, Universitas Diponegoro during the research.

\section{Authors'contributions}

PK and IGRH carried out data collection through laboratory experimental studies and drafted the article. IS and ACK designed the conception or design of the work, data analysis and interpretation and critical revision of the article. All the authors read and final approval of the version to be published.

\section{Funding}

No any Research Funds or Grants.

\section{Availability of data and materials}

All data generated or analysed during this study are included in this published article. The raw data obtained available from the corresponding author upon reasonable request.

\section{References}

1. Ahamed, A., Chen, C.L., Rajagopal, R., Wu, D., Mao, Y., Ho, I. J. R., Lim, J.W., Wang. J,Y. Multi-phased anaerobic baffled reactor treating food waste. Bioresour. Technol. 182, 239-244 (2015).

2. Hahn, M. J., Figueroa, L. A. Pilot scale application of anaerobic baffled reactor for biologically enhanced primary treatment of raw municipal wastewater. Water Res 87, 494-502 (2015). 
3. Kondusamy, D and Kalamdhad, A. S. 2014. Pre-treatment and anaerobic digestion of food waste for high rate methane production - A review. J Environ Chem Eng 2, 1821-1830 (2014).

4. Aziz,, Basheer, F., Sengar, A., Irfanullah, Khan, S.U., Farooqi, I. H. Biological wastewater treatment (anaerobic-aerobic) technologies forsafe discharge of treated slaughterhouse and meatprocessing wastewater. Sci Total Environ 686, 681-708 (2019).

5. Gong, Fan, A., Zhang, H., Luo, L., Liang, H. Cow manure anaerobic fermentation effluent treatment by oxygen-based membrane aerated biofilm reactor. Chem Eng J 395, 125116 (2020).

6. Luz, F.C., Cordiner, S., Manni, A., Mulone, V., Rocco, V.: Anaerobic digestion of coffee grounds soluble fraction at laboratory scale: evaluation of the biomethane potential. Appl. Energy 207, 166-175 (2017).

7. Luz, F.C., Cordiner, S., Manni, A., Mulone, V., Rocco, V. Biomass fast pyrolysis in screw reactors: Prediction of spent coffee grounds bio-oil production through a monodimensional model. Energy Convers Manag 168, 98-106 (2018).

8. Deublein, D., \& Steinhauser, A. Biogas from Waste and Renewable Resources: An Introduction, Second Edition. In Biogas from Waste and Renewable Resources: An Introduction, Second Edition. https://doi.org/10.1002/9783527632794 (2010).

9. Emmanuel, S.A., Yoo, J., Kim, E.J., Chang, J.S., Park, Y.I., Koh, S.C.: Development of functional composts using spent coffee grounds, poultry manure and biochar through microbial bioaugmentation. J. Environ. Sci. Health B 52(11), 802-811 (2017).

10. Gafar, S. dan P. A. Teknologi Dekafeinasi Kopi Robusta. Dinamika Penelitian Industri, 28, 87-93 (2017).

11. Ballesteros, L. F., Teixeira, J. A., \& Mussatto, S. I. Chemical, Functional, and Structural Properties of Spent Coffee Grounds and Coffee Silverskin. Food Bioproc Tech, 7(12), 3493-3503. https://doi.org/10.1007/s11947-014-1349-z. (2014).

12. Caetano, N. S., Silvaa, V. F. M., \& Mata, T. M. Valorization of Coffee Grounds for Biodiesel Production. Chem Eng Trans, 26, 267-272. https://doi.org/10.3303/CET1226045. (2012).

13. Murthy, P. S., \& Madhava Naidu, M. Sustainable Management of Coffee Industry By-Products and Value Addition - A review. Resour Conserv Recycl, 66, 45-58.

https://doi.org/10.1016/j.resconrec.2012.06.005 (2012).

14. Herawati, D. A., and Wibawa, A. A. Pengaruh Pretreatment Jerami Padi pada Produksi Biogas dari Jerami Padi dan Sampah Sayur Sawi Hijau Secara Batch. 4(1), 25-29. https://doi.org/10.22146/jrekpros.572 (2010).

15. Adilaksma,C. The Influence of Effective Microorganisms 4 (EM4) Addition to Biogas Production from Water Hyacinth. DOI: 13140/RG.2.2.15372.21122 (2017).

16. Orfanoudaki, A., Makridakis, G., Maragkaki, A., Fountoulakis, M.S., Kallithrakas-Kontos, N.G., Manios, T. Anaerobic Co-digestion of Pig Manure and Spent Coffee Grounds for Enhanced Biogas Production. Waste Biomass Valor, 11:4613-4620 (2020).

17. SNI (Standart Nasional Indonesia, Indonesia National Standard) 19-7030-2004 
18. Syaichurrozi, I., Budiyono, Sumardiono, S. Predicting kinetic model of biogas production and biodegradability organic materials: Biogas production from vinasse at variation of $\mathrm{COD} / \mathrm{N}$ ratio. Bioresour. Technol. 149, 390-397 (2013).

19. Mao, C., Wang, X., Xi, J., Feng, Y., Ren, G. Linkage of kinetic parameters with process parameters and operational conditions during anaerobic digestion. Energy 135, 352-360 (2017).

20. Gunes, B., Stokes, J., Davis, P., Connolly, C., Lawler, J. Pre-treatments to enhance biogas yield and quality from anaerobic digestion of whiskey distillery and brewery wastes: A review. Sustain. Energy Rev. 113, 109281 (2019).

21. APHA. Standard Methods for the Examination of Water and Wastewater (21st edn) (2012).

22. Labatut, R., Angenent, L.T., Scott, N.,. Biochemical methane potential and biodegradability of complex organic substrates. Bioresour. Technol. 102 (3), 2255-2264 (2011).

23. Meng, Y., Li, S., Yuan, H., Zou, D., Liu, Y., Zhu, B., Chufo, A., Jaffar, M., Li, X., Evaluating biomethane production from anaerobic mono- and co-digestion of food waste and floatable oil (FO) skimmed from food waste. Bioresour. Technol. 185, 7-13 (2015).

24. Feng, Lin, Y. Integrated processes of anaerobic digestion and pyrolysis for higher bioenergy recovery from lignocellulosic biomass: A brief review. Renew. Sustain. Energy Rev. 77, 1272-1287 (2017).

25. Dai, X, Li X, Zhang D, Chen Y, Dai L. Simultaneous enhancement of methane production and methane content in biogas from waste activated sludge and perennial ryegrass anaerobic co-digestion: the effects of $\mathrm{pH}$ and $\mathrm{C} / \mathrm{N}$ ratio. Bioresour Technol;216:323-30 (2016).

26. Neshat, S.A., Mohammadi, M., Najafpour, G.D., Lahijani, P.: Anaerobic codigestion of animal manures and lignocellulosic residues as a potent approach for sustainable biogas production. Renew.

Sustain. Energy Rev. 79, 308-322 (2017)

27. $\mathrm{Xu}_{\text {, }} \mathrm{Li}, \mathrm{Y}$., Ge, X., Yang, L., Li, Y. Anaerobic digestion of food waste-Challenges and opportunities. Bioresour. Technol. 247, 1047-1058 (2018).

28. Megawati, M. Pengaruh Penambahan EM4 (Effective Microorganism-4) pada Pembuatan Biogas dari Eceng Gondok dan Rumen Sapi. Jurnal Bahan Alam Terbarukan, 3(2), 42-49. https://doi.org/10.15294/jbat.v3i2.3696 (2014).

29. Budiyono, Widiasa, I.N., Johari, S., Sunarso. The kinetic of biogas production rate from cattle manure in batch mode. Int. J. Chem. Biol. Eng. 3 (1), 39-44 (2010).

30. Zhu, B., Gikas, P., Zhang, R., Lord, J., Jenkins, B., Li, X. Characteristics and biogas production potential of municipal solid wastes pretreated with a rotary drum reactor. Bioresour. Technol. 100,1122-1129 (2009).

31. Patil, J.H., Raj, M.A., Muralidhara, P.L., Desai, S.M., Raju, G.K.M., 2012. Kinetics of anaerobic digestion of water hyacinth using poultry litter as inoculum. Int. J. Environ. Sci. Dev. 3 (2), 94-98.

32. Adiga, S., Ramya, R., Shankar, B.B., Patil, J.H., Geetha, C.R. Kinetics of anaerobic digestion of water hyacinth, poultry litter, cow manure and primary sludge: a comparative study. Int. Conf. Biotechnol. Environ. Manag. 14 (2), 73-78 (2012). 
33. Li, Jin, Y., Li, H., Borrion, A., Yu, Z., Li, J. Kinetic studies on organic degradation and its impacts on improving methane production during anaerobic digestion of food waste. Appli. Energy 213, 136147 (2018).

\section{Figures}

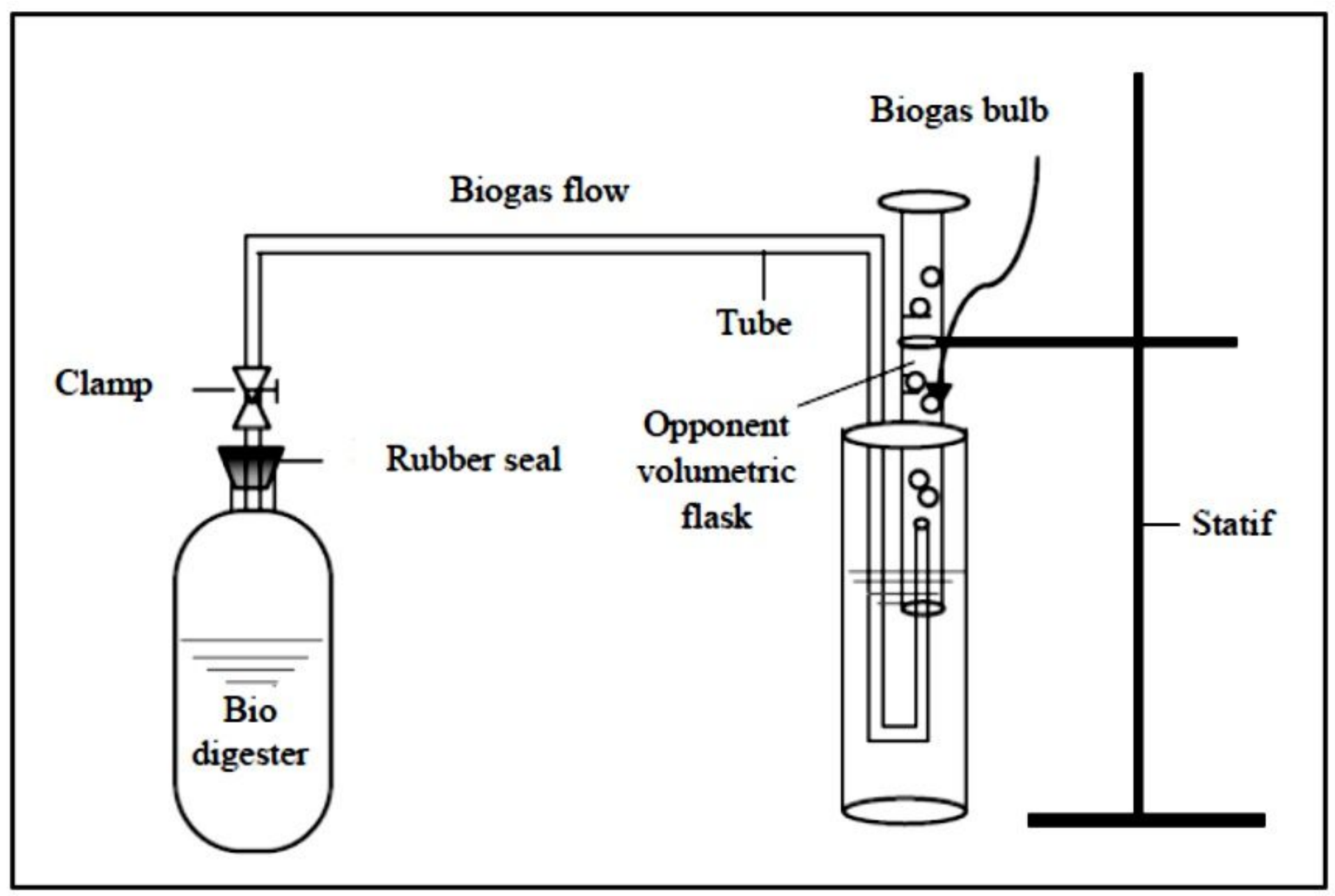

Figure 1

Equipment of biogas production 

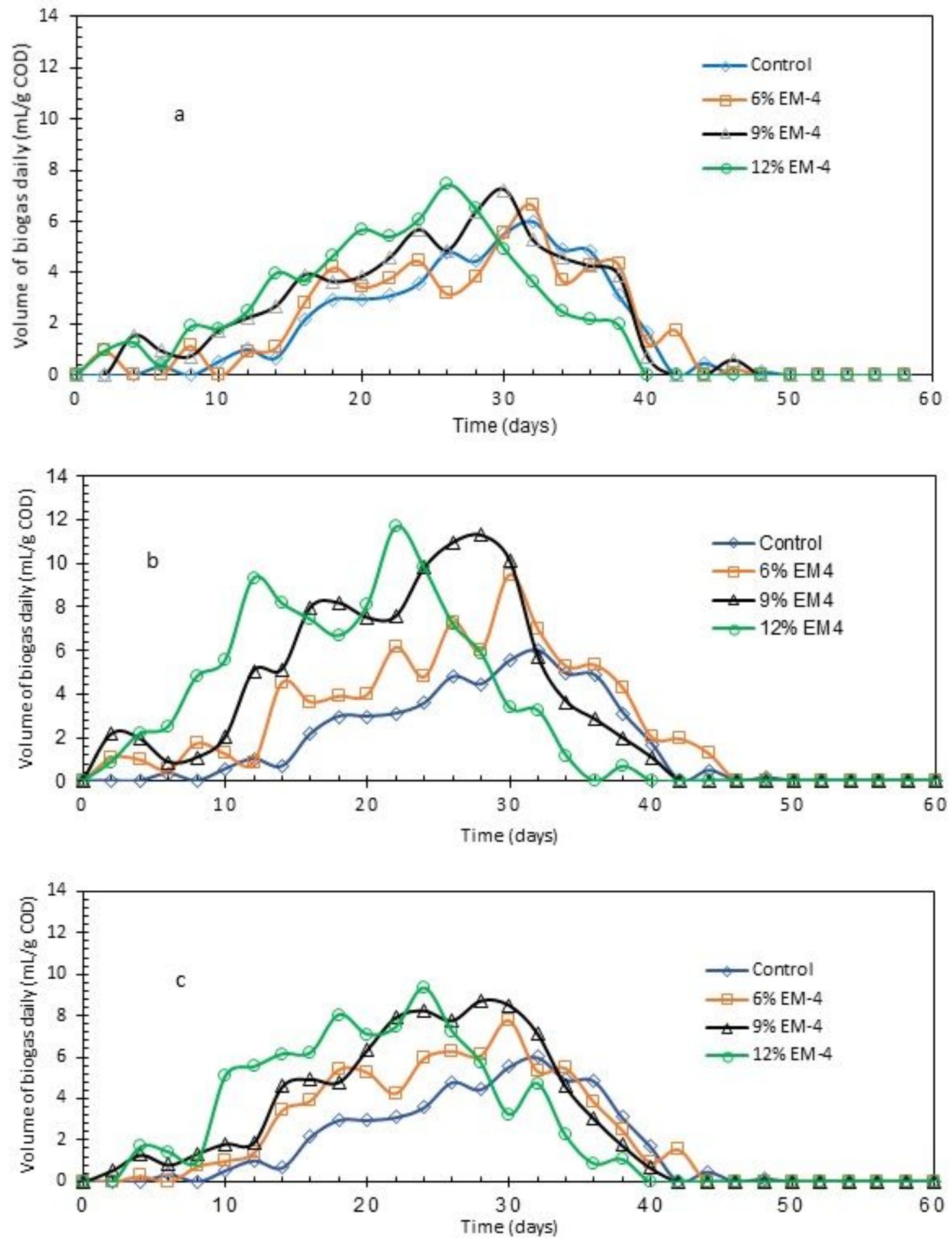

Figure 2

Daily Biogas production at various EM-4 loading (a). $\mathrm{pH}=5$, (b). $\mathrm{pH}=7$, (c) $\cdot \mathrm{pH}=9$ 

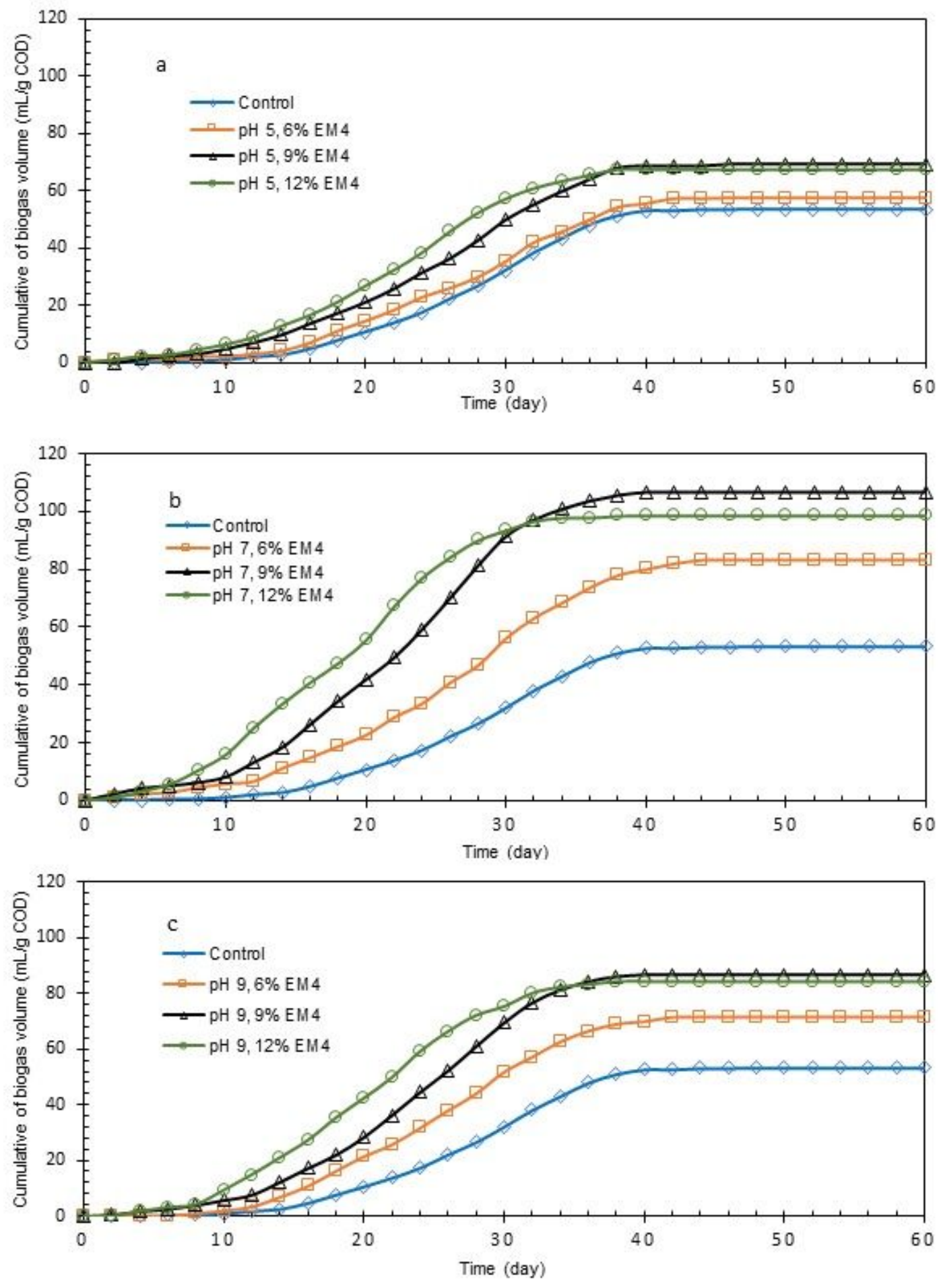

Figure 3

Cumulative of biogas production of (a) $\mathrm{pH}$ of 5, (b). $\mathrm{pH}$ of 7, and (c). $\mathrm{pH}$ of 9. 

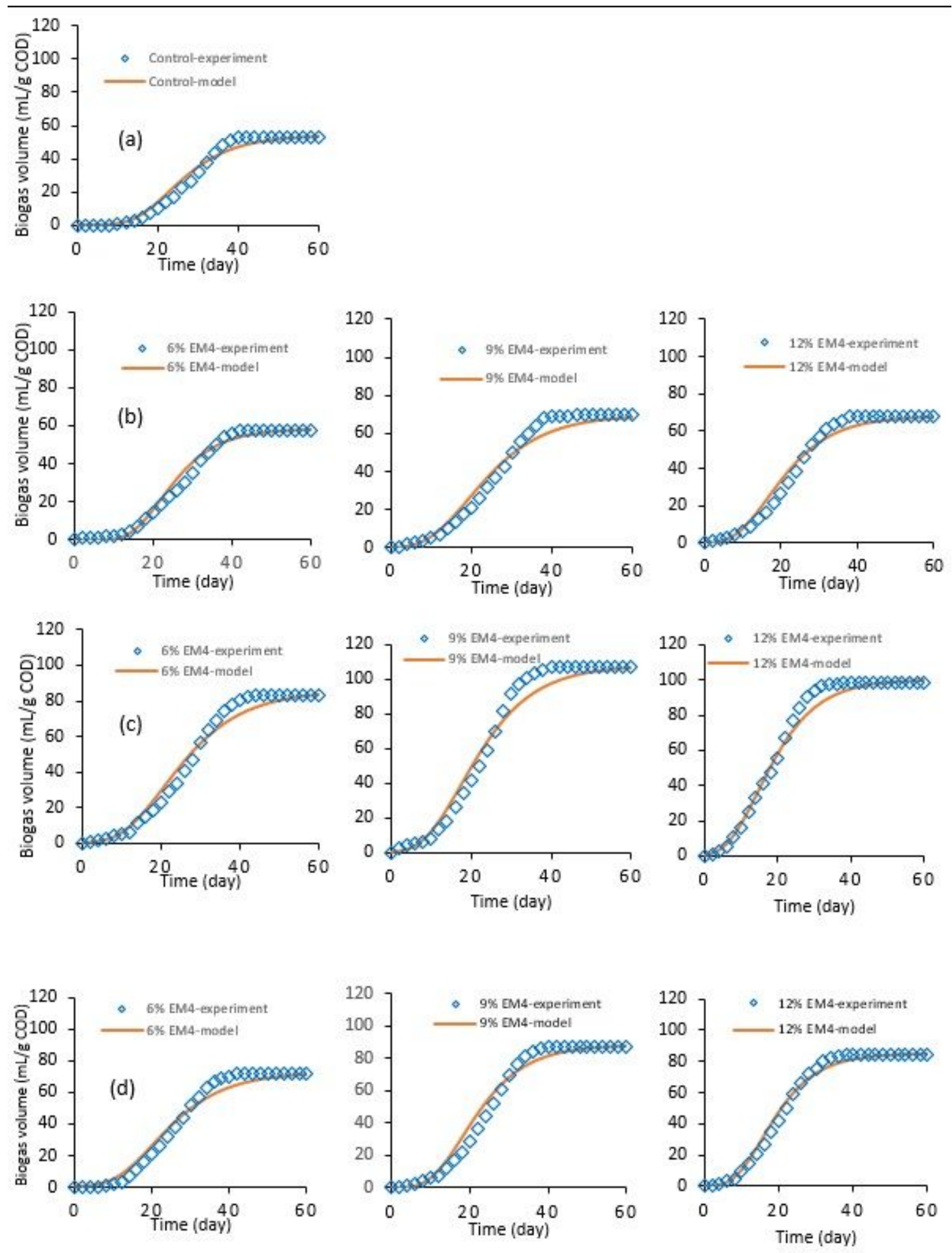

\section{Figure 4}

Cumulative biogas production: (a). Control, (b). $\mathrm{pH}$ of 5, (c). $\mathrm{pH}$ of 7, (d). $\mathrm{pH}$ of 9 